\title{
Should We Continue to Use the Cockcroft-Gault Formula?
}

\author{
Rafik Helou \\ Department of Internal Medicine, Bertinot Juel Hospital, Chaumont en Vexin, France
}

\section{Key Words}

Cockcroft-Gault formula - Modification of diet in renal disease formula $\cdot$ Glomerular filtration rate $\cdot$ Chronic kidney disease $\cdot$ Creatinine clearance

\begin{abstract}
Background/Aims: Although the National Kidney Disease Education Program recommends use of the modification of diet in renal disease (MDRD) formula to estimate the glomerular filtration rate (GFR), most drug-dosing recommendations and clinical practices employ the Cockcroft-Gault (CG) formula. The quality score of the original MDRD study was better than that of the original CG study, although the imprecision sources were very similar between the formulas. To address whether CG should be abandoned in favour of MDRD in chronic kidney disease (CKD) management, we performed a literature review on the topic. Methods: We reviewed 27 articles comparing CG and MDRD in terms of bias, precision, accuracy, and the risk of misclassifying by two CKD stages. Results: In the chronic renal disease population, MDRD was more precise, safer and more accurate than CG at predicting the GFR, with two exceptions: CG was clearly superior in CKD patients with a normal serum creatinine $(\mathrm{SCr})$ and results were discordant in patients with advanced renal failure. In diabetic populations with normal and near-normal GFR, the decline in renal function in diabetics was better screened by CG. In diabetics with renal impairment, MDRD is
\end{abstract}

more accurate than CG. In healthy patients, in subjects with normal SCr and in elderly patients, MDRD was not superior. Based on the risk of misclassifying by $\geq 2$ CKD stages, neither formula could be safely applied in diabetic, low body mass index, advanced liver disease, chronic heart failure, or hospitalized patients. Conclusions: CG still has an interest in screening the decline in renal function in subjects with normal SCr who are at risk, such as diabetics and stage 1 and 2 CKD patients, as well as healthy subjects enrolled in clinical trials and pharmacokinetic studies. Thus, it may be early to replace CG by MDRD in drug studies. CG still is the better formula in the elderly. Both formulas are not safe in some populations.

Copyright $\odot 2010$ S. Karger AG, Basel

\section{Introduction}

The National Kidney Disease Education Program and other scientific communities recommend using the modification of diet in renal disease (MDRD) $[1,2]$ formula to approximate renal function through the glomerular filtration rate (GFR). However, most drug-dosing recommendations are based on the Cockcroft-Gault (CG) [3] formula, which estimates the creatinine clearance $(\mathrm{CrCl})$. Additionally, CG remains widely used in clinical practice and recent articles and reviews continue to support its use $[4-6,45,47,63]$.

\section{KARGER}

Fax +4161306 1234

E-Mail karger@karger.ch

www.karger.com
(C) 2010 S. Karger AG, Basel

$1660-2110 / 10 / 1163-0172 \$ 26.00 / 0$

Accessible online at:

www.karger.com/nec
Dr. Rafik Helou, MD

Department of Internal Medicine, Bertinot Juel Hospital

34 bis rue Pierre Budin

FR-60240 Chaumont en Vexin (France)

Fax +33 344495 456, E-Mail heloumail@yahoo.com 
Table 1. a Comparison of the patient characteristics and methodologies used in deriving the CG and MDRD formulas

\begin{tabular}{|c|c|c|}
\hline & CG & MDRD \\
\hline Study population & $\begin{array}{l}\text { Consecutive patients who had two or more } \\
\text { 24-hour CrCls determined at Queen Mary } \\
\text { Veterans Hospital }\end{array}$ & $\begin{array}{l}\text { Patients enrolled in a multicenter, controlled trial of } \\
\text { the effects of dietary protein restriction and blood } \\
\text { pressure on the progression of kidney disease }\end{array}$ \\
\hline Inclusion criteria & $\begin{array}{l}\text { Being in steady state defined as values for } \mathrm{SCr} \\
\text { differed by }<20 \%\end{array}$ & $\begin{array}{l}\text { Age of } 18-70 \text { years } \\
\mathrm{CrCl}<70 \mathrm{ml} / \mathrm{min} / 1.73 \mathrm{~m}^{2} \\
\text { Mean arterial pressure } \leq 125 \mathrm{~mm} \mathrm{Hg}\end{array}$ \\
\hline Exclusion criteria & & $\begin{array}{l}\text { A body weight under } 80 \% \text { or over } 160 \% \text { of standard } \\
\text { body weight } \\
\text { Diabetes mellitus requiring insulin therapy }{ }^{\mathrm{a}} \\
\text { Urinary protein excretion exceeding } 10 \mathrm{~g} / \text { day }\end{array}$ \\
\hline Total included patients & 505 & $\begin{array}{l}1,628 \\
983 \delta / 645 ㅇ\end{array}$ \\
\hline Training sample & 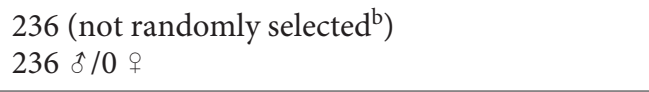 & 1,070 (randomly selected) \\
\hline Validation sample & $505^{\mathrm{c}}$ & 558 \\
\hline Gold standard & $\mathrm{CrCl}$ & ${ }^{125}$ I-iothalamate measured GFR \\
\hline Renal function measurement & $\mathrm{CrCl}: 72.7 \pm 36.6 \mathrm{ml} / \mathrm{min}$ & GFR: $40 \pm 21 \mathrm{ml} / \mathrm{min} / 1.73 \mathrm{~m}^{2}$ \\
\hline Creatinine assay & Jaffé (Technicon Autoanalyser method N-11B) & Kinetic alkaline picrate (Beckman CX3) \\
\hline Weight, kg & Mean: 72 & Mean \pm SD: $79.6 \pm 16.8$ \\
\hline Age & Range: 18-92 & Mean \pm SD: $51 \pm 13$ \\
\hline Statistical analysis & $\begin{array}{l}\text { Simple linear regression by plotting age against } \\
\text { creatininuria }\left(\mathrm{mg} \cdot \mathrm{kg}^{-1} \cdot \text { day }^{-1}\right)\end{array}$ & $\begin{array}{l}\text { Stepwise multiple regression of log-transformed data, } \\
\text { based on demographic, serum, and urine variables }\end{array}$ \\
\hline QUADAS score [8] & $45 \%{ }^{\mathrm{d}}$ & $82 \%$ \\
\hline $\begin{array}{r}{ }^{a} \text { Only } 6 \% \text { of the MDRD sa } \\
\text { b Patients were rejected fro } \\
>20 \%(n=173) \text {, if the } 24 \text {-hour } \\
{ }^{c} \text { Validation sample was no } \\
{ }^{d} \text { Details of the Quality As }\end{array}$ & $\begin{array}{l}\text { ample were diabetic. } \\
\text { om the CG training sample if the difference betw } \\
\text { creatinine excretion was }<10 \mathrm{mg} / \mathrm{kg}(\mathrm{n}=31) \text {, or } \\
\text { ot separate from the training sample. }\end{array}$ & $\begin{array}{l}\text { een values for } 24 \text {-hour creatinine excretion differed by } \\
\text { if the records were inadequate }(n=65) \text {. } \\
\text { DAS) score determination are shown in Appendix } 1 \text {. }\end{array}$ \\
\hline
\end{tabular}

Cockcroft and Gault derived their equation from a population of 236 male hospitalized patients who had 2 $\mathrm{CrCl}$ determinations that differed by $<20 \%$. The mean of $2 \mathrm{CrCl}$ determinations were used to derive the formula, considering age and patient weight. A 15\% reduction was recommended when applying the formula to women. Although the original purpose of the formula was to estimate $\mathrm{CrCl}, \mathrm{CG}$ was later proposed to directly predict $\mathrm{GFR}$ [7]. In contrast, the 4 -variable MDRD resulted from a retrospective multicentre controlled trial of the effects of dietary protein restriction and strict blood pressure control on kidney disease progression. The MDRD takes into account serum creatinine (SCr), age, gender and race.
The major weakness of the original CG study has been the non-separation between the training and validation samples. When comparing the quality of the original CG- and MDRD-deriving studies overall, the MDRD study clearly prevails (Appendix 1, table 1 ). However, this is of secondary importance if the CG formula performs at least comparably to the MDRD formula. Considering the success of the MDRD, the main goal of the present review was to determine whether the CG formula should be abandoned or if it still has a place in renal function analysis. In the original MDRD study, several subgroups were excluded or insufficiently represented, including the elderly, diabetics, patients with end-stage renal disease or 
Table 1. $\mathbf{b}$ Sources of imprecision in the CG and MDRD formulas

\begin{tabular}{lll}
\hline & CG & MDRD \\
\hline Age $^{\mathrm{a}}$ & + & + \\
Weight $^{\mathrm{b}}$ & ++ & 0 \\
Race $^{\mathrm{c}}$ & 0 & ++ \\
Variability of SCr measurement methods $_{\quad}$ & & + \\
Sex $^{\mathrm{e}}$ & ++ & $-/+$ \\
Serum albumin $^{\mathrm{f}}$ & $-/+$ & ++ \\
\hline
\end{tabular}

a The dates of birth of two persons of the same age could differ by 364 days.

${ }^{b}$ Weight imprecision has multiple sources: tool used and its imprecision, hour of measurement, clothes, rounding effect, etc.

${ }^{c}$ It depends on which factor the physician would choose for multiracial subjects.

${ }^{\mathrm{d}}$ For the 4-variable MDRD, the SCr of the original sample was re-essayed in 2004 with an enzymatic method traceable to the IDMS assay, and the formula was re-expressed using standardized SCr values.

${ }^{\mathrm{e}}$ Although it seems strange that sex could be a source of imprecision, in this instance it is. Suppose that the reasons for dif-

ferences in the GFR between females and males are based on hormonal or muscular factors. These factors, or the force of their influence, are not constant at all ages. For instance, we wonder if the female corrective factor (0.85) in CG is necessary in the elderly, with the frequent sarcopenia in both sexes. We could say the same thing about the usefulness of a female factor in the very low BMI group or in cirrhotic patients.

${ }^{\mathrm{f}}$ Serum albumin level influences tubular creatinine secretion as in nephrotic syndrome, making the creatinine-based formulas overestimate the GFR [54]. In this case, the use of the original 6-variable MDRD may be more relevant, because it accounts for the albumin level.

renal disease with normal SCr levels, over- or underweight patients, dialysis patients, kidney transplant recipients, patients receiving immunosuppressive or corticosteroid treatment, frequently hospitalized patients, or patients with other serious medical conditions [9-11]. Additional studies have been performed to validate the MDRD in these subgroups. Therefore, an additional goal of our work was to compare the MDRD and CG formulas in some of these subgroups.

\section{Methods}

We reviewed 27 papers comparing CG and MDRD. Studies were included if they contained a gold-standard GFR measure, such as inulin or isotopic methods. We typically compared CG with the abbreviated 4-variable MDRD formula; however, in 6 articles $[4,5,12-16]$ only the 6 -variable MDRD formula was reported. Since the 2 MDRD formulas have relatively similar accuracies [1], we do not expect that the use of both the 4- and 6-variable formulas is a major limitation.

Because the sample populations and methods were quite variable across the studies, we avoided calculating a pooled bias or pooled accuracy. In addition, large-pooled means would not confirm the usefulness of a formula in a particular population. Instead, we conducted a 'stratified' review, studying gathered homogenous samples wherever possible. Results were grouped based on patient characteristics (geriatrics, diabetics, renal disorders, nutrition disorders, healthy and normal SCr, and others).
Although the correlation coefficient (r) was frequently reported, we did not use it for comparisons since $r$ measures the strength of the relationship but not the agreement between 2 variables [17, 18]. The same issue applied to the determination coefficient $R^{2}$; although sometimes considered to be a precision measure, $\mathrm{R}^{2}$ is simply the square of the correlation coefficient in the simple linear regression.

CrCl estimated by CG as well as measured and estimated GFRs were adjusted for body surface area and expressed in $\mathrm{ml} / \mathrm{min} /$ $1.73 \mathrm{~m}^{2}$ in all but 4 articles $[4,5,13,26]$. In statistical tables, an empty cell indicates that information was not reported. Results using the MDRD are shown in bold or in italics (tables 2-7) if they over- or underperform those using CG.

We classified SCr measurement methods into: alkaline picrate methods (Jaffé methods) including modified ones, enzymatic methods and isotope-dilution mass spectrometry methods (IDMS).

\section{Definitions of Performance Measures}

Estimation bias, also called systematic error, refers to an estimation method for which the average of repeated estimates deviates from the true value [19]. Precision is the measure of the statistical variance of an estimation procedure [19]. Unlike bias, precision is a random error and has no direction [20]. Unbiased but imprecise estimates may arise when the measurement itself is imprecise or when key elements are missing. The missing elements may not lead to overall bias but may be relevant for a subgroup [21]. Accuracy is the closeness of the agreement between the measurement result and the true value [20,22]. Like bias measures, accuracy measures typically consider the difference between the estimated and true values, but not the direction of this difference. 


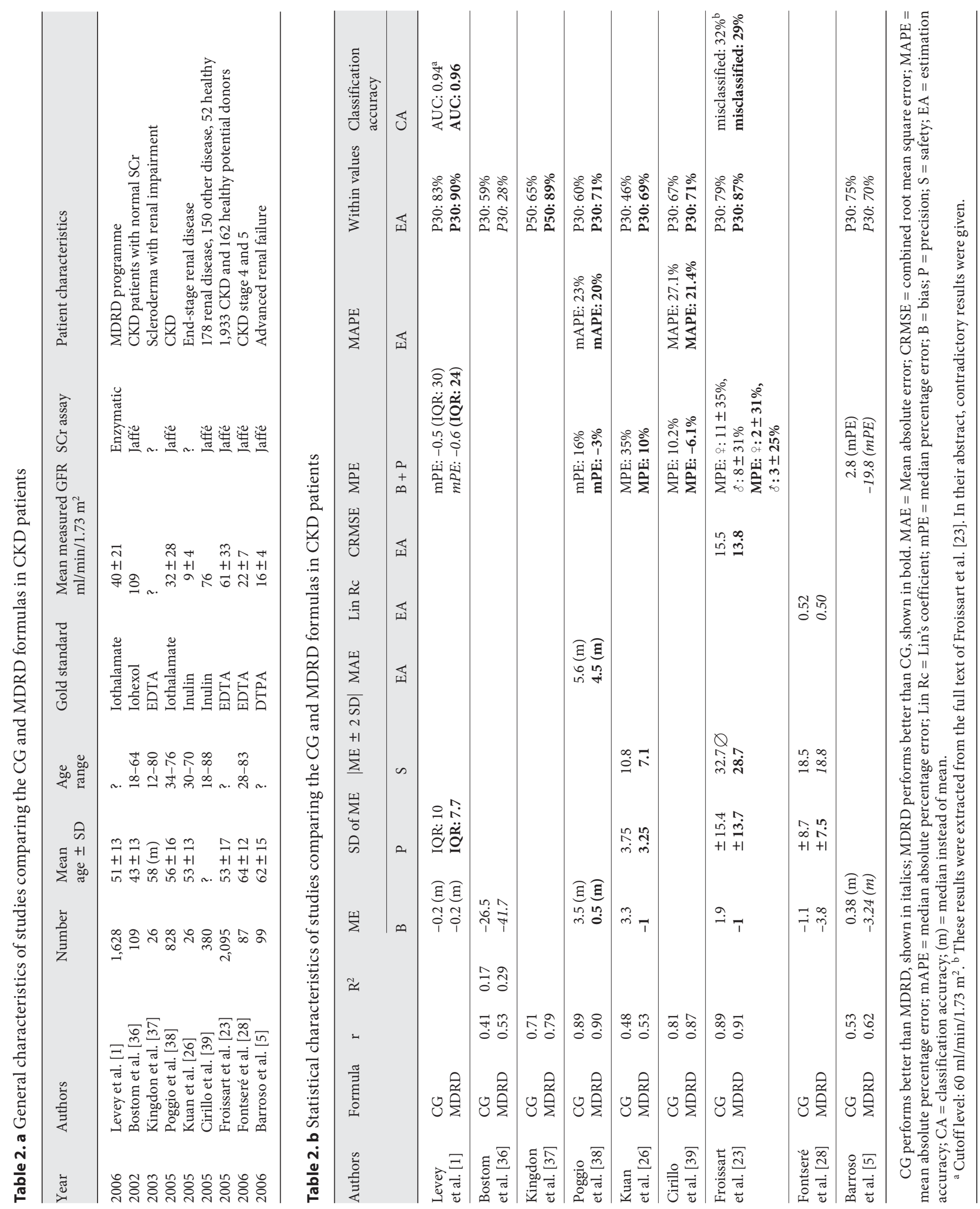



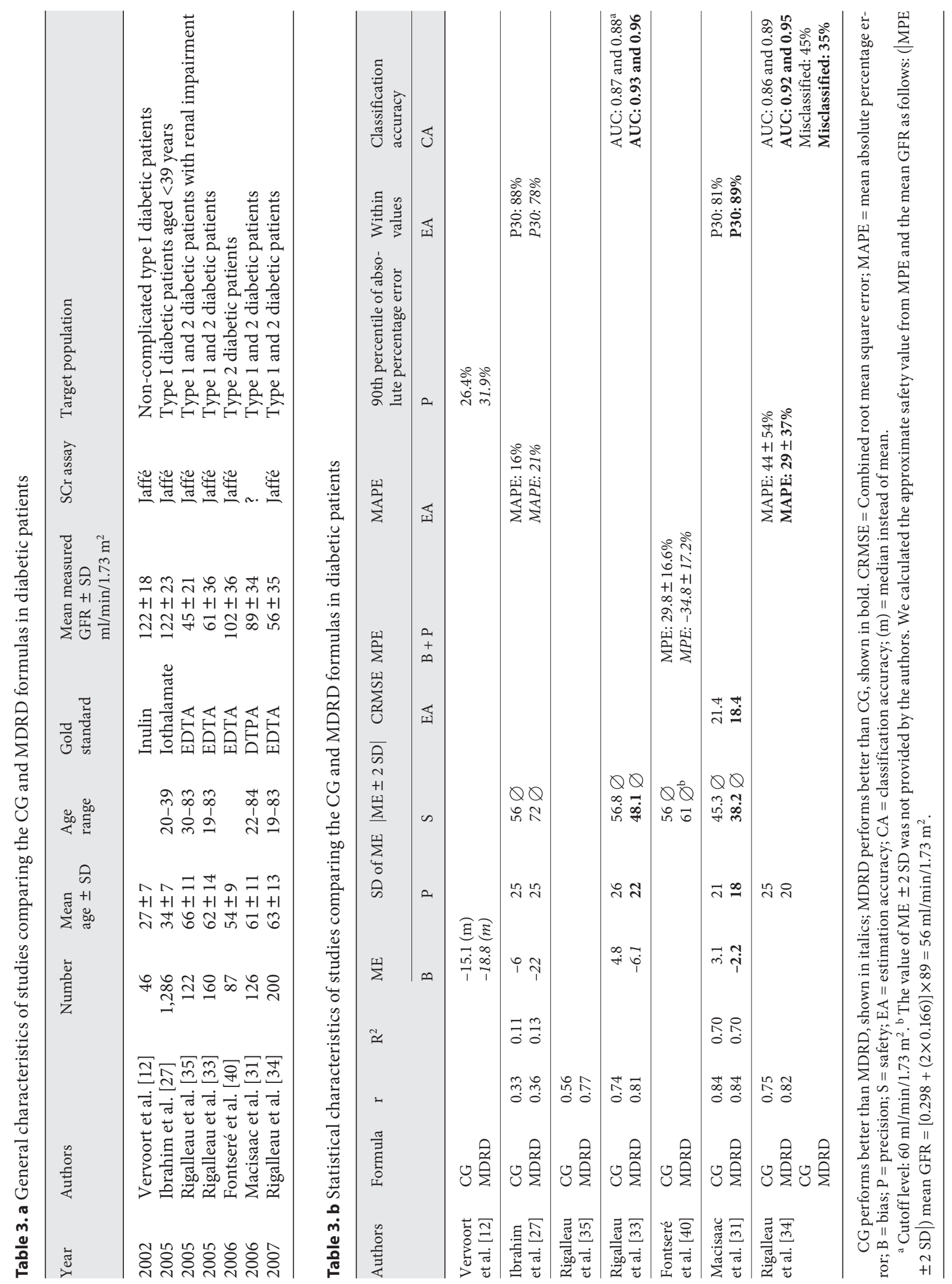


\section{Definition of Errors (Differences)}

The arithmetic error is the difference between the estimated and measured GFR values (estimated GFR - measured GFR ${ }^{1}$ ). The percentage error or relative error is defined as the arithmetic error relative to the measured GFR (estimated GFR - measured GFR)/measured GFR, expressed as a percentage [21]. The absolute error $^{2}$ and absolute percentage error are defined as the absolute values of the arithmetic error and percentage error, respectively.

\section{Measures of Performance}

Bias Measures

- Mean error (ME) is the mean of all arithmetic errors [20].

- Median error is the median of all arithmetic errors; it replaces the ME in several articles.

- Mean percentage error (MPE) is the mean of all percentage errors.

- Median percentage error is the median of all percentage errors; it replaces the MPE in several articles.

\section{Precision Measures}

- Standard deviation (SD) $)^{3}$ of arithmetic, percentage, absolute, or absolute percentage errors [21].

- Interquartile range of errors, defined as the width of the 25 th to the 75th percentile.

- The 90th percentile of the percentage absolute error (used in 3 studies) $[2,12,15]$.

- Limits of agreement of the Bland-Altman [17, 18] plotting method $^{4}$.

Estimation Accuracy Measures

- Mean absolute error (MAE) [20] or median absolute error (mAE).

- Mean absolute percentage error or median absolute percentage error.

- Lin's coefficient, also called the coefficient of concordance [24], measures accuracy (nearness of the reduced major axis of the data to the line of perfect concordance) and precision (tightness of the data around the reduced major axis). Lin's coefficient $<0.90$ indicates poor accuracy [25].

- Combined root mean square error is defined as:

$$
\sqrt{\frac{\sum(\text { EstimatedGFR }- \text { MeasuredGFR })^{2}}{N}+S D^{2}}
$$

where $\mathrm{SD}$ is the standard deviation of the difference.

1 We chose the order shown because it was used by all but 3 studies [1, $12,13]$, which used the opposite order for this equation (measured GFR estimated GFR). The sign of the results of these 3 studies has been changed only for the purpose of our review.

2 Some authors preferred to call the arithmetic error the 'absolute bias', such as in table 6 of Froissart et al. [23]. However, the absolute error should have no sign and is not a measure of bias, but of accuracy.

3 Some authors provided the standard error of the mean (SEM) instead of SD $[13,16]$. We calculated SD for these results as $\mathrm{SD}=\mathrm{SEM} \times \sqrt{ } N$, where $\mathrm{N}$ is the number of patients.

4 Bland-Altman plots, which test bias uniformity over the whole range of values, were available in 15 studies. Limits of agreement (ME $\pm 2 \mathrm{SD}$ ) were only provided in 12 studies [13, 16, 23, 26-34]. In articles that did not provide them, the SD of the ME and of the MPE were extracted from the distance between the limits of agreement of the Bland-Altman plot [26-29].
- $\mathrm{P}_{30}$ is the percentage of estimates within $30 \%$ of the measured GFR [21]. Some authors calculated estimates within 15\% $\left(\mathrm{P}_{15}\right)$ or $50 \%\left(\mathrm{P}_{50}\right) . \mathrm{P}_{50}$ was used when the $\mathrm{P}_{30}$ was not provided. We focused on $\mathrm{P}_{30}$ because the Kidney Disease Outcomes Quality Initiative guidelines recommend a $\mathrm{P}_{30}$ value of $90 \%$ [46]. It should be noted that this value was not attained by MDRD or CG in the 27 articles, except in the MDRD validation sample [1].

\section{Classification Accuracy Measures}

Classification accuracy refers to the ability to classify patients into different chronic kidney disease (CKD) stages. Authors primarily used 2 cutoffs: $30 \mathrm{ml} / \mathrm{min} / 1.73 \mathrm{~m}^{2}$ and $60 \mathrm{ml} / \mathrm{min} / 1.73 \mathrm{~m}^{2}$. Accuracy measures included the sensitivity, specificity, area under the curve (AUC), and number of misclassified patients.

\section{Acceptability or Safety Limits}

No acceptability thresholds were proposed for any parameter in any of the reviewed articles. Therefore, we developed a safety tool for the purpose of this review. Whenever possible, we calculated the absolute value of the $\mathrm{ME}$ and $2 \mathrm{SDs}:|\mathrm{ME} \pm 2 \mathrm{SD}| \mathrm{Pa}-$ tients with acceptability threshold values $>30 \mathrm{ml} / \mathrm{min} / 1.73 \mathrm{~m}^{2}$ (wideness of CKD stage 2 or 3 ) were at a significant risk of being misclassified by 2 stages (see Appendix 2 for more explanations). Such values were therefore flagged by the symbol $\varnothing$

\section{Results}

\section{Renal Disease Group}

The MDRD was more precise, safe, and accurate than the CG in predicting the GFR in CKD, with 2 notable exceptions. In CKD patients with a normal SCr, the CG was clearly superior [36]; and in cases of advanced renal failure (GFR <30), the study results were discordant $[5,26$, 28] (table 2). This discordance was also found in kidney transplant recipients in the review of White et al. [53].

\section{Diabetics Group}

In studies where the safety measure could be calculated [27, 31, 33, 40], neither formula was safe for use in diabetics (table 3). The MDRD always underestimated GFR, and in cases of normal or near-normal GFR [12, 27, 40], the decline in renal function in diabetics seemed to be better screened by CG.

It was unclear whether the diabetic sample populations were totally independent in 2 articles published by Rigalleau et al. $[33,34]$. The settings, age range, and results (e.g. AUC and SD of the ME) were very similar. These characteristics led us to consider these 2 papers as a single study.

Diabetes was insufficiently represented in the original MDRD study, comprising only $6 \%$ of the sample [1]. A recent study using a pooled individual patient database 
Table 4. a General characteristics of studies comparing the CG and MDRD formulas in healthy and normal SCr subjects

\begin{tabular}{|c|c|c|c|c|c|c|c|c|}
\hline Year & Authors & Number & $\begin{array}{l}\text { Mean age } \\
\pm S D\end{array}$ & $\begin{array}{l}\text { Age } \\
\text { range }\end{array}$ & Gold standard & $\begin{array}{l}\text { Mean measured } \\
\text { GFR } \pm \mathrm{SD} \\
\mathrm{ml} / \mathrm{min} / 1.73 \mathrm{~m}^{2}\end{array}$ & SCr assay & Patient characteristics \\
\hline 2002 & Vervoort et al. [12] & 46 & $28 \pm 6$ & & Inulin & $107 \pm 11$ & Jaffé & Healthy \\
\hline 2003 & Lin et al. [41] & 100 & $41 \pm 10$ & $18-62$ & Iothalamate/DTPA & $113 \pm 21$ & Jaffé & Healthy potential kidney donor \\
\hline 2005 & Poggio et al. [38] & 457 & $42 \pm 10$ & $28-55$ & Iothalamate & $106 \pm 18$ & Jaffé & Healthy potential kidney donor \\
\hline 2005 & Verhave et al. [48] & 850 & $48 \pm 15$ & $18-93$ & DTPA & $99 \pm 20$ & $\begin{array}{l}\text { Enzymatic } \\
\text { and Jaffé }\end{array}$ & Patients with normal SCr \\
\hline
\end{tabular}

Table 4. $\mathbf{b}$ Statistical characteristics of studies comparing the CG and MDRD formulas in healthy and normal SCr subjects

\begin{tabular}{|c|c|c|c|c|c|c|c|c|c|c|c|}
\hline \multirow[t]{2}{*}{ Authors } & \multirow[t]{2}{*}{ Formula } & \multirow[t]{2}{*}{$\mathrm{r}$} & \multirow[t]{2}{*}{$\mathrm{R}^{2}$} & $\mathrm{ME}$ & $\begin{array}{l}\text { SD of } \\
\mathrm{ME}\end{array}$ & $\begin{array}{l}\mid \mathrm{ME} \pm \\
2 \mathrm{SD} \mid\end{array}$ & MAE & MPE & $\begin{array}{l}\text { 90th percentile } \\
\text { of absolute per- } \\
\text { centage error }\end{array}$ & MAPE & \multirow[t]{2}{*}{$\begin{array}{l}\text { Within } \\
\text { values }\end{array}$} \\
\hline & & & & B & $P$ & $S$ & EA & B & $\mathrm{P}$ & EA & \\
\hline $\begin{array}{l}\text { Vervoort et al. [12] } \\
\text { (subgroup) }\end{array}$ & $\begin{array}{l}\text { CG } \\
\text { MDRD }\end{array}$ & & & $\begin{array}{l}-13.1(\mathrm{~m}) \\
-\mathbf{1 0 . 7}\end{array}$ & & & & & $\begin{array}{l}26.6 \% \\
\mathbf{2 5 . 5} \%\end{array}$ & & \\
\hline Lin et al. [41] & $\begin{array}{l}\text { CG } \\
\text { MDRD }\end{array}$ & $\begin{array}{l}0.24 \\
0.15\end{array}$ & $\begin{array}{l}0.06 \\
0.02\end{array}$ & $\begin{array}{l}16.8 \\
-18.3\end{array}$ & & & $\begin{array}{l}37.9 \\
28.7\end{array}$ & & & $\begin{array}{l}\text { mAPE: } 23 \% \\
\text { mAPE: } \mathbf{2 2} \%\end{array}$ & $\begin{array}{l}\text { P30: 45\% } \\
\text { P30: 65\% }\end{array}$ \\
\hline $\begin{array}{l}\text { Poggio et al. [38] } \\
\text { (subgroup) }\end{array}$ & $\begin{array}{l}\text { CG } \\
\text { MDRD }\end{array}$ & $\begin{array}{l}0.41 \\
0.36\end{array}$ & & $\begin{array}{l}1.9(\mathrm{~m}) \\
-9(m)\end{array}$ & & & $\begin{array}{l}14.9(\mathrm{~m}) \\
15.9(\mathrm{~m})\end{array}$ & $\begin{array}{l}\text { mPE: } 2 \% \\
\text { mPE: }-9 \%\end{array}$ & & $\begin{array}{l}\text { mAPE: } 14 \% \\
\text { mAPE: } 16 \%\end{array}$ & $\begin{array}{l}\text { P30: } 85 \% \\
\text { P30: 86\% }\end{array}$ \\
\hline Verhave et al. [48] & & & & & & & & & & & \\
\hline $\begin{array}{l}\text { Enzymatic SCr } \\
\text { Jaffé SCr }\end{array}$ & $\begin{array}{l}\text { CG } \\
\text { MDRD } \\
\text { CG } \\
\text { MDRD }\end{array}$ & & $\begin{array}{l}0.32 \\
0.34 \\
0.31 \\
0.34\end{array}$ & $\begin{array}{l}-4.9 \\
-12.4 \\
-20.6 \\
28.8\end{array}$ & & & & & & & $\begin{array}{l}\text { P30: } 87 \% \\
\text { P30: } 89 \% \\
\text { P30: } 71 \% \\
\text { P30: } 51 \%\end{array}$ \\
\hline
\end{tabular}

CG performs better than MDRD, shown in italics; MDRD performs better than CG, shown in bold. $(\mathrm{m})=$ Median instead of mean; MAE $=$ mean absolute error; $\mathrm{mPE}=$ median percentage error; $\mathrm{MAPE}=$ mean absolute percentage error; $\mathrm{mAPE}=$ median absolute percentage error; $\mathrm{B}=$ bias; $\mathrm{P}=$ precision; $\mathrm{S}=$ safety; EA = estimation accuracy.

showed an improvement in MDRD accuracy in 3 diabetic cohorts after SCr calibration [49]. We did not include this study in our work, because the research did not include separate CG-MDRD comparisons for each cohort.

\section{Healthy and Normal SCr Group}

In all 4 studies reviewed that considered patients with healthy and normal SCr (table 4), the MDRD underestimated the GFR. The study by Vervoort et al. [12] compared CG to the 6-variable MDRD. To our knowledge, the accuracy between the 4- and the 6-variable MDRD formulas has not yet been tested in the healthy and normal SCr population. In the 3 other studies, CG was clearly less biased, while the accuracy results were often similar.

It is generally accepted that MDRD is inaccurate in subjects with low SCr values [50, author reply] or with high
GFR values, and that these inaccuracies persist even after SCr calibration [49]. For this reason, the National Kidney Disease Education Program and other organizations currently recommend reporting a numeric value only for MDRD-estimated GFR of $<60 \mathrm{ml} / \mathrm{min} / 1.73 \mathrm{~m}^{2}$. There are two problems with this recommendation. First, although the above threshold is useful for defining CKD, it does not represent the lower limit of the normal GFR range [46]. Second, the GFR of an at-risk individual for CKD (due to diabetes, medications, high blood pressure, age, etc.) could drop by a third (e.g. from 90 to $60 \mathrm{ml} / \mathrm{min} / 1.73 \mathrm{~m}^{2}$ ) without being detected by the MDRD estimations. Because pharmacokinetic studies and clinical trials are usually first conducted in a healthy population, it may still be too early to replace CG-estimated $\mathrm{CrCl}$ values with MDRDestimated GFR values in drug studies [52]. 
Table 5. a General characteristics of studies comparing the CG and MDRD formulas in elderly patients

\begin{tabular}{|c|c|c|c|c|c|c|c|}
\hline Year & Authors & Number & $\begin{array}{l}\text { Mean age } \\
\pm S D\end{array}$ & Gold standard & $\begin{array}{l}\text { Mean measured } \\
\text { GFR } \pm \mathrm{SD} \\
\mathrm{ml} / \mathrm{min} / 1.73 \mathrm{~m}^{2}\end{array}$ & SCr assay & Patient characteristics \\
\hline 2003 & $\begin{array}{l}\text { Fehrman-Ekholm and } \\
\text { Skeppholm [14] }\end{array}$ & 52 & $82 \pm N A$ & Iohexol & $68 \pm 11$ & $?$ & $\begin{array}{l}\text { Volunteer elderly healthy } \\
\text { persons }\end{array}$ \\
\hline 2005 & Lamb et al. $[4]$ & 46 & $80 \pm 5$ & EDTA & $54 \pm 17$ & IDMS & Old patients \\
\hline 2005 & $\begin{array}{l}\text { Froissart et al. [23] } \\
\text { (Strate) }\end{array}$ & 595 & $73 \pm 5$ & EDTA & $\begin{array}{l}46 \pm 26 \text { (females) } \\
43 \pm 29 \text { (males) }\end{array}$ & Jaffé & Subgroup $>65$ years \\
\hline 2005 & Burkhardt et al. [13] & 61 & $75 \pm 7$ & Inulin & $96 \pm 39$ & Jaffé & Geriatric inpatients \\
\hline
\end{tabular}

Table 5. $\mathbf{b}$ Statistical characteristics of studies comparing the CG and MDRD formulas in elderly patients

\begin{tabular}{|c|c|c|c|c|c|c|c|c|c|}
\hline \multirow[t]{2}{*}{ Authors } & \multirow[t]{2}{*}{ Formula } & \multirow[t]{2}{*}{$\mathrm{r}$} & \multirow[t]{2}{*}{$\mathrm{R}^{2}$} & \multirow{2}{*}{$\begin{array}{l}\mathrm{ME} \\
\mathrm{B}\end{array}$} & \multirow{2}{*}{$\begin{array}{l}\text { SD of } \\
\text { the ME } \\
P\end{array}$} & \multirow{2}{*}{$\begin{array}{l}|\mathrm{ME} \pm 2 \mathrm{SD}| \\
\mathrm{S}\end{array}$} & \multirow{2}{*}{$\begin{array}{l}\text { 90th percentile } \\
\text { of absolute error }\end{array}$} & \multirow{2}{*}{$\begin{array}{l}\text { 90th percentile of abso- } \\
\text { lute percentage error } \\
\text { P }\end{array}$} & \multirow{2}{*}{$\begin{array}{l}\mathrm{AUC}^{\mathrm{a}} \\
\mathrm{CA}\end{array}$} \\
\hline & & & & & & & & & \\
\hline Fehrman-Ekholm and & CG & 0.71 & 0.50 & & & & & & \\
\hline Skeppholm [14] & MDRD & 0.73 & 0.53 & & & & & & \\
\hline \multirow[t]{2}{*}{ Lamb et al. [4] } & CG & 0.88 & 0.77 & -3.8 & \pm 8 & 19.8 & & & \\
\hline & MDRD & 0.91 & 0.82 & 8.6 & \pm 10 & 28.6 & & & \\
\hline \multicolumn{10}{|l|}{ Froissart et al. [23] groups $^{b}$} \\
\hline \multirow[t]{2}{*}{ Males with low GFR } & CG & & & -2.3 & \pm 7.2 & 16.7 & 12 & $38 \%$ & \\
\hline & MDRD & & & 0.5 & \pm 6.7 & 13.9 & 10 & $37 \%$ & \\
\hline \multirow[t]{2}{*}{ Males with high GFR } & CG & & & -14.5 & \pm 10.4 & $35.3 \varnothing$ & 27 & $34 \%$ & \\
\hline & MDRD & & & -5.9 & \pm 12.1 & $30.1 \varnothing$ & 22 & $26 \%$ & \\
\hline \multirow[t]{2}{*}{ Females with low GFR } & CG & & & -0.1 & \pm 8.0 & 16.1 & 12 & $41 \%$ & \\
\hline & MDRD & & & 1.2 & \pm 8.2 & 17.6 & 13 & $39 \%$ & \\
\hline \multirow[t]{2}{*}{ Females with high GFR } & CG & & & -10.7 & \pm 12.2 & $35.1 \varnothing$ & 24 & $30 \%$ & \\
\hline & MDRD & & & -1.6 & \pm 11.5 & 24.6 & 19 & $22 \%$ & \\
\hline \multirow[t]{2}{*}{ Burkhardt et al. [13] } & CG & & & -40 & \pm 56 & $152 \varnothing$ & & & 0.89 and 0.87 \\
\hline & MDRD & & & -20 & \pm 58 & $136 \varnothing$ & & & 0.85 and $\mathbf{0 . 9 8}$ \\
\hline
\end{tabular}

CG performs better than MDRD shown in italics; MDRD performs better than CG shown in bold. $\mathrm{B}=$ Bias; $\mathrm{P}=$ precision; $\mathrm{S}=$ safety; $\mathrm{CA}=$ classification accuracy.

${ }^{a}$ AUC for cutoff levels at 90 and $60 \mathrm{ml} / \mathrm{min}$, respectively. ${ }^{\mathrm{b}}$ Low GFR $<60 \mathrm{ml} / \mathrm{min} / 1.73 \mathrm{~m}^{2}$ and high $\mathrm{GFR}>60 \mathrm{ml} / \mathrm{min} / 1.73 \mathrm{~m}^{2}$.

\section{Geriatrics Group}

We found 3 articles $[4,13,14]$ that compared estimations using MDRD and CG to a gold standard in elderly populations. Additionally, a subgroup aged $>65$ years was extracted from Froissart et al. [23] (table 5). FehrmanEkholm et al. [14] did not report a statistical tool other than the coefficients of correlation and of determination. Burkhardt et al. [13] did not adequately explain their very large SD of the ME (the largest one found in our review) obtained using both MDRD and CG. This large value led us to question the precision of the gold standard in their study; it was the only study that used one shot of inulin rather than a constant perfusion as a gold standard. The one-shot inulin method has been validated in children [43], but not in elderly patients. A previous paper by the same authors also reported a similarly large SD of $\mathrm{ME}$ [42]. In addition, the confidence interval of the mean measured GFR was $96 \pm 39 \mathrm{ml} / \mathrm{min} / 1.73 \mathrm{~m}^{2}$. Thus, moderate and advanced CKD was not sufficiently represented in the elderly sample population.

When reviewing the Froissart et al. [23] study, we found that neither formula could be safely applied in el- 
Table 6. a General and statistical characteristics of studies comparing the CG and MDRD formulas in low BMI patients

\begin{tabular}{|c|c|c|c|c|c|c|c|c|c|}
\hline \multirow[t]{2}{*}{ Year } & \multirow[t]{2}{*}{ Reference } & \multirow[t]{2}{*}{ Number } & \multirow{2}{*}{$\begin{array}{l}\text { Gold } \\
\text { standard }\end{array}$} & \multirow[t]{2}{*}{ Definition } & & $\mathrm{ME}$ & $\pm \mathrm{SD}$ of $\mathrm{ME}$ & $|\mathrm{ME} \pm 2 \mathrm{SD}|$ & MPE \\
\hline & & & & & & B & $\mathrm{P}$ & S & B \\
\hline 2005 & Cirillo et al. [39] & 45 & Inulin & BMI $<21$ & $\begin{array}{l}\text { CG } \\
\text { MDRD }\end{array}$ & & & & $\begin{array}{l}\text { MPE: }-18 \% \\
\text { MPE: }-\mathbf{1 2} \%\end{array}$ \\
\hline 2005 & Froissart et al. [23] & 94 & EDTA & $\mathrm{BMI}<18.5$ & $\begin{array}{l}\text { CG } \\
\text { MDRD }\end{array}$ & $\begin{array}{r}6.5 \\
12\end{array}$ & $\begin{array}{l} \pm 17.7 \\
\pm 24.8\end{array}$ & $\begin{array}{l}42 \varnothing \\
62 \varnothing\end{array}$ & \\
\hline
\end{tabular}

Table 6. $\mathbf{b}$ General and statistical characteristics of studies comparing the CG and MDRD formulas in obese patients

\begin{tabular}{|c|c|c|c|c|c|c|c|c|c|}
\hline \multirow[t]{2}{*}{ Year } & \multirow[t]{2}{*}{ Reference } & \multirow[t]{2}{*}{ Number } & \multirow{2}{*}{$\begin{array}{l}\text { Gold } \\
\text { standard }\end{array}$} & \multirow[t]{2}{*}{ Definition } & & ME & $\pm \mathrm{SD}$ & \multirow{2}{*}{$\frac{|\mathrm{ME} \pm 2 \mathrm{SD}|}{\mathrm{S}}$} & \multirow{2}{*}{$\begin{array}{l}\text { MPE } \\
\text { B }\end{array}$} \\
\hline & & & & & & B & $\mathrm{P}$ & & \\
\hline 2005 & Cirillo et al. [39] & 91 & Inulin & $\mathrm{BMI}>30$ & $\begin{array}{l}\text { CG } \\
\text { MDRD }\end{array}$ & & & & $\begin{array}{l}\text { MPE: } 19 \% \\
\text { MPE: } \mathbf{- 2 \%}\end{array}$ \\
\hline 2005 & Froissart et al. [23] & 279 & EDTA & $\mathrm{BMI}>30$ & $\begin{array}{l}\text { CG } \\
\text { MDRD }\end{array}$ & $\begin{array}{c}9 \\
-2.5\end{array}$ & $\begin{array}{l}18.7 \\
11.6\end{array}$ & $\begin{array}{l}46.4 \varnothing \\
25.7\end{array}$ & \\
\hline
\end{tabular}

CG performs better than MDRD, shown in italics; MDRD performs better than CG, shown in bold. $\mathrm{B}=\mathrm{Bias}$; $\mathrm{P}=$ precision; $\mathrm{S}=$ safety. No accuracy measure was available.

derly males (aged $>65$ years) with a high GFR. However, it would have been preferable if the sample had been stratified from 75 years. In Western countries, the concept of an 'old' patient diverges from the World Health Organization definition. In France, the mean age in institutions for old persons is 85 years, and the Ministry of Health defines the geriatric department as a ward for patients older than 75 years.

Lamb et al. [4] used the gold standard of SCr measurements (IDMS) and EDTA as GFR reference method. Their mean age was $80 \pm 5$ years and mean GFR was 54 $\pm 17 \mathrm{ml} / \mathrm{min} / 1.73 \mathrm{~m}^{2}$. Until larger studies are performed, this article is the most relevant in elderly. It found that CG was safer and less biased than MDRD in this population.

The accordance of CG and MDRD is very poor in elderly populations ( $\kappa$ coefficient of 0.44 ), and these formulas cannot be used interchangeably to measure renal function in this population [51]. For these reasons, we recommend that only CG be used in elderly patients.

\section{Nutrition Disorders Group}

Body mass index (BMI) subgroups were adequately studied in 2 studies $[23,39]$ (table 6), and the results of these studies indicated that MDRD is safer and less biased when used in patients with a high BMI. Neither formula can be safely used in patients with a low BMI.

\section{Other Groups}

The results of other populations studied but not classified above are shown in table 7 . The population targets studied included patients with rheumatoid arthritis, advanced liver disease, chronic heart failure, AfricanAmericans with hypertension and a kidney disease cohort, hospitalized patients, heart transplant recipients, and former kidney donors. Except in cases of advanced liver disease, where CG is more biased but somewhat safer, more accurate, and more precise, in all other populations the MDRD prevailed. Neither formula was safe in heart transplant recipients, former kidney donors, or in patients with advanced liver disease. In hospitalized patients, we could not calculate the safety measure; however, with median absolute percentage errors of 71 and 53\% for CG and MDRD, respectively, neither formula would be safe.

\section{Discussion}

Each time the average measured GFR of the sample was $>90 \mathrm{ml} / \mathrm{min} / 1.73 \mathrm{~m}^{2}[12,27,36,38,40,48]$, CG performed better that MDRD, except in one study [41]. We believe that CG remains relevant in those patient populations who generally have a normal SCr. 
Table 7. a General characteristics of studies comparing the CG and MDRD formulas in non-classified populations

\begin{tabular}{|c|c|c|c|c|c|c|c|c|}
\hline Year & Reference & Number & $\begin{array}{l}\text { Mean age } \\
\pm \mathrm{SD}\end{array}$ & Age range & Gold standard & $\begin{array}{l}\text { Mean measured } \\
\text { GFR }( \pm \mathrm{SD}), \\
\mathrm{ml} / \mathrm{min} / 1.73 \mathrm{~m}^{2}\end{array}$ & SCr assay & Patient characteristics \\
\hline 2008 & Karstila et al. [6] & 81 & $66 \pm 11$ & $41-86$ & ${ }^{51} \mathrm{Cr}-\mathrm{EDTA}$ & $44(\mathrm{~m})$ & Enzymatic & Rheumatoid arthritis \\
\hline 2006 & MacAulay et al. [16] & 57 & $50 \pm 11$ & $16-67$ & ${ }^{99 \mathrm{~m}} \mathrm{Tc}-\mathrm{DTPA}$ & 83 & $?$ & Advanced liver disease \\
\hline 2006 & Smilde et al. [30] & 110 & $58 \pm 12$ & & ${ }^{125}$ I-iothalamate & $73 \pm 27$ & $?$ & Chronic heart failure \\
\hline 2001 & Lewis et al. [15] & 1,703 & $54 \pm 11$ & & ${ }^{125}$ I-iothalamate & $57 \pm 23$ & Jaffé & AASK cohort \\
\hline 2005 & Poggio et al. [44] & 107 & $65 \pm 15$ & $39-82$ & ${ }^{125}$ I-iothalamate & $17 \pm 18$ & Jaffé & Hospitalized patients \\
\hline 2006 & Delanaye et al. [29] & 27 & $57 \pm 12$ & & ${ }^{51} \mathrm{Cr}-\mathrm{EDTA}$ & $39 \pm 15$ & Jaffé & $\begin{array}{l}\text { Heart transplant } \\
\text { recipients }\end{array}$ \\
\hline 2006 & Ibrahim et al. [32] & 112 & $40 \pm 10$ & & Iohexol & $72 \pm 12$ & Jaffé & Former kidney donors \\
\hline
\end{tabular}

Table 7. $\mathbf{b}$ Statistical characteristics of studies comparing the CG and MDRD formulas in non-classified populations

\begin{tabular}{|c|c|c|c|c|c|c|c|c|c|c|c|}
\hline \multirow[t]{2}{*}{ Reference } & \multirow[t]{2}{*}{ Formula } & \multirow[t]{2}{*}{$\mathrm{r}$} & \multirow[t]{2}{*}{$\mathrm{R}^{2}$} & $\mathrm{ME}$ & $\begin{array}{l} \pm \mathrm{SD} \text { of } \\
\mathrm{ME}\end{array}$ & $|\mathrm{ME} \pm 2 \mathrm{SD}|$ & MAE & MPE & $\begin{array}{l}\text { Other accuracy } \\
\text { measures }\end{array}$ & $\begin{array}{l}\text { 90th percentile } \\
\text { of absolute per- } \\
\text { centage error }\end{array}$ & Lin Rc \\
\hline & & & & B & $\mathrm{P}$ & $S$ & A & B & A & $\mathrm{P}$ & $A \& P$ \\
\hline $\begin{array}{l}\text { Karstila } \\
\text { et al. [6] }\end{array}$ & $\begin{array}{l}\text { CG } \\
\text { MDRD }\end{array}$ & $\begin{array}{l}0.90 \\
0.87\end{array}$ & & & & & & $\begin{array}{l}20 \% \\
20 \%\end{array}$ & $\begin{array}{l}\text { PPV }^{\mathrm{a}}: 0.88 \\
\text { PPV: } \mathbf{0 . 9 0}\end{array}$ & & \\
\hline $\begin{array}{l}\text { MacAulay } \\
\text { et al. [16] }\end{array}$ & $\begin{array}{l}\text { CG } \\
\text { MDRD }\end{array}$ & $\begin{array}{l}0.80 \\
0.87\end{array}$ & $\begin{array}{l}0.65 \\
0.76\end{array}$ & $\begin{array}{r}15.4 \\
3.5\end{array}$ & $\begin{array}{l} \pm 26 \\
\pm 32\end{array}$ & $\begin{array}{l}67.4 \varnothing \\
67.5 \varnothing\end{array}$ & $\begin{array}{l}23.6 \\
23.4\end{array}$ & $\begin{array}{c}15.7 \\
4\end{array}$ & $\begin{array}{l}\text { P30: } 65 \% \\
\text { P30: } 62 \%\end{array}$ & & \\
\hline $\begin{array}{l}\text { Smilde } \\
\text { et al. [30] }\end{array}$ & $\begin{array}{l}\text { CG } \\
\text { MDRD }\end{array}$ & $\begin{array}{l}0.79 \\
0.82\end{array}$ & $\begin{array}{l}0.63 \\
0.68\end{array}$ & & & $\begin{array}{l}41 \varnothing^{\mathrm{b}} \\
41 \varnothing\end{array}$ & & $\begin{array}{c}-6 \pm 25 \% \\
-12 \pm 22.5 \%\end{array}$ & $\begin{array}{l}\text { P30: } 76 \% \\
\text { P30: 80\% }\end{array}$ & & \\
\hline $\begin{array}{l}\text { Lewis } \\
\text { et al. [15] }\end{array}$ & $\begin{array}{l}\text { CG } \\
\text { MDRD }\end{array}$ & $\begin{array}{l}0.85 \\
0.91\end{array}$ & $\begin{array}{l}0.72 \\
0.82\end{array}$ & $\begin{array}{l}-2.67 \\
-0.94\end{array}$ & & & $\begin{array}{l}8.3(\mathrm{~m}) \\
6.27\end{array}$ & & $\begin{array}{l}\text { mAPE: } 16.4 \% \\
\text { mAPE: } \mathbf{1 2 . 4 \%}\end{array}$ & $\begin{array}{l}39.6 \% \\
31.6 \%\end{array}$ & \\
\hline $\begin{array}{l}\text { Poggio } \\
\text { et al. [44] }\end{array}$ & $\begin{array}{l}\mathrm{CG} \\
\mathrm{MDRD}\end{array}$ & $\begin{array}{l}0.66 \\
0.71\end{array}$ & & $\begin{array}{l}8.2(\mathrm{~m}) \\
6.2(\mathrm{~m})\end{array}$ & & & $\begin{array}{l}8.3(\mathrm{~m}) \\
7.2(\mathrm{~m})\end{array}$ & $\begin{array}{l}71 \% \\
53 \%\end{array}$ & $\begin{array}{l}\text { mAPE: } 71 \% \\
\text { mAPE: } \mathbf{5 3} \%\end{array}$ & & $\begin{array}{l}0.46 \\
0.57\end{array}$ \\
\hline $\begin{array}{l}\text { Delanaye } \\
\text { et al. [29] }\end{array}$ & $\begin{array}{l}\text { CG } \\
\text { MDRD }\end{array}$ & $\begin{array}{l}0.71 \\
0.83\end{array}$ & $\begin{array}{l}0.50 \\
0.69\end{array}$ & $\begin{array}{l}19.9 \\
12\end{array}$ & $\begin{array}{l} \pm 13.8 \\
\pm 8.5\end{array}$ & $\begin{array}{l}47.5 \varnothing \\
29\end{array}$ & & & $\begin{array}{l}\text { P30: } 23 \% \\
\text { P30: } 43 \%\end{array}$ & & \\
\hline $\begin{array}{l}\text { Ibrahim } \\
\text { et al. [32] }\end{array}$ & $\begin{array}{l}\text { CG } \\
\text { MDRD }\end{array}$ & $\begin{array}{l}0.60 \\
0.71\end{array}$ & $\begin{array}{l}0.36 \\
0.50\end{array}$ & $\begin{array}{r}3.4 \\
-6.6\end{array}$ & $\begin{array}{l} \pm 13.6 \\
\pm 9.5\end{array}$ & $\begin{array}{l}30.6 \varnothing \\
25.6\end{array}$ & & $\begin{array}{r}5.6 \pm 21.5 \% \\
-8.3 \pm 14.1 \%\end{array}$ & $\begin{array}{l}\text { P30: } 87 \% \\
\text { P30: } 96 \%\end{array}$ & & \\
\hline
\end{tabular}

CG performs better than MDRD, shown in italics; MDRD performs better than CG, shown in bold. AASK cohort = African-American Study of hypertension and Kidney Disease; MAE = mean absolute error; Lin Rc = Lin's coefficient; B = bias; $\mathrm{P}=$ precision; $\mathrm{S}=$ safety; $\mathrm{A}=\mathrm{accuracy} ;(\mathrm{m})=$ median instead of mean; $\mathrm{mAPE}=$ median absolute percentage error.

${ }^{a}$ Predictive positive value (PPV) for cutoff level at $90 \mathrm{ml} / \mathrm{min} / 1.73 \mathrm{~m}^{2}$. ${ }^{\mathrm{b}}$ The value of $\mathrm{ME} \pm 2 \mathrm{SD}$ was not provided by authors. We calculated the approximate safety value from MPE and mean GFR as follows: $(|\mathrm{MPE} \pm 2 \mathrm{SD}|) \times$ mean GFR.

The major argument against the use of CG is that it cannot be re-expressed for IDMS-traceable SCr values. In addition, the SCr method used to develop the formula is no longer in use and samples from the study are not available [62]. However, the success of CG is not due to the original CG study itself (as the study contained several weaknesses), but to its validation in several later studies compared to both measured $\mathrm{CrCl}$ values and reference GFR measurement methods [7, 55-61]. Those studies used different SCr methods; we believe that at least one could be re-expressed using IDMS-traceable SCr assay.

A study by Stevens et al. [64] showed that the MDRD had greater concordance with measured GFR for recommended drug dosage than the CG, for all subgroups tested, while the mean of CG-estimated $\mathrm{CrCl}$ was closer to the measured GFR than MDRD-estimated values in almost all subgroups, as well as in the whole population. 
Regrettably, the ME \pm SD for each formula were not reported. Beside the fact that it was a simulation and not a pharmacokinetics study, discordance exceeding 1 level of dosing was not calculated. Actually, 12 of 15 drugs tested had more than 2 levels of dosing. Missing more than 1 level reflects a high risk of toxicity and could be a consequence of the imprecision of a formula.

The main limitation of our study is that, although our review is the largest to date to compare CG and MDRD, it is still not exhaustive.

The CG formula remains of interest in screening declining renal function in subjects with normal SCr who are at risk, including diabetics, patients with stage 1 or 2 CKD, and healthy subjects enrolled in pharmacokinetics studies or clinical trials. In elderly individuals, CG remains the most accurate formula. Neither formula was safe in some populations, including diabetics, patients with a low BMI, advanced liver disease, or chronic heart failure, and hospitalized patients. When applying the formulas in those populations, there was a significant risk of misclassifying patients by two stages. The CG may require an adjustment factor to be applied using $\mathrm{SCr}$ values measured by newly established assay procedures, as was done with the MDRD formula.

\section{Appendix 1}

Quality Assessment for Diagnostic Accuracy Studies questionnaire [8] for the original MDRD and CG studies.

\begin{tabular}{ll}
\hline 1 & Was the spectrum of patients representative of the patients who will receive the test in practice? \\
\hline 3 & Were selection criteria clearly described? \\
\hline 4 & Is the reference standard likely to correctly classify the target condition? \\
\hline 5 & $\begin{array}{l}\text { Is the time period between reference standard and index test short enough to be reasonably sure that the target condition did not change } \\
\text { between the two tests? }\end{array}$ \\
\hline 6 & Did the whole sample or a random selection of the sample, receive verification using a reference standard of diagnosis? \\
\hline 8 & Did patients receive the same reference standard regardless of the index test result? \\
\hline 9 & Was the reference standard independent of the index test (i.e. the index test did not form part of the reference standard)? \\
\hline 10 & Was the execution of the index test described in sufficient detail to permit replication of the test? \\
\hline 11 & Was the execution of the reference standard described in sufficient detail to permit its replication? \\
\hline 13 & Were the index test results interpreted without knowledge of the results of the reference standard? \\
\hline 14 & Were the reference standard results interpreted without knowledge of the results in the index test? \\
\hline
\end{tabular}

\begin{tabular}{|c|c|c|}
\hline Questions & CG & MDRD \\
\hline 1 & $\begin{array}{l}\text { No: no women were included in the training sample. Of the entire sample, only } 4 \% \text { were women. Few } \\
\text { elderly patients were included (only } 17 \text { patients were }>80 \text { years of age) }\end{array}$ & $\begin{array}{l}\text { No: there were very } \\
\text { strict eligibility and } \\
\text { exclusion criteria [9-11] }\end{array}$ \\
\hline 2 & $\begin{array}{l}\text { No: patients excluded from the training sample were retained in the validation sample, including } 65 \\
\text { patients with inadequate records }\end{array}$ & Yes \\
\hline 3 & $\begin{array}{l}\text { No: } \mathrm{CrCl} \text { may be a reference estimator of renal function, but 'the mean of two } \mathrm{CrCl} \text { measurements } \\
\text { separated by an unknown delay' is not }\end{array}$ & Yes \\
\hline 4 & $\begin{array}{l}\text { No: the CG study was retrospective with the mean of } 2 \mathrm{CrCl} \text { measurements used as reference. We do not } \\
\text { know the delay between the } 2 \mathrm{CrCl} \text { measurements. Weight and age are also important variables, and it is } \\
\text { unknown whether they were ascertained at the first or second } \mathrm{CrCl} \text { measurement }\end{array}$ & Yes \\
\hline $5-8$ & Yes & Yes \\
\hline 9 & No: no detail was given about how and when urine was collected & Yes [9-11] \\
\hline $10-12$ & Not relevant & Not relevant \\
\hline 13 & Yes & Yes \\
\hline 14 & No: the training group was reduced in size from 249 to 236 individuals, without explanation & Yes \\
\hline
\end{tabular}




\section{Appendix 2}

We defined our safety condition as $|\mathrm{ME} \pm 2 \mathrm{SD}|<30 \mathrm{ml} / \mathrm{min} / 1.73 \mathrm{~m}^{2}$. In the following 4 examples (fig. A-D) extracted from 2 articles studied in the current review, we show graphically that each time this threshold was exceeded, there was a significant risk of misclassifying those patients close to the edge of a given CKD stage by two stages.

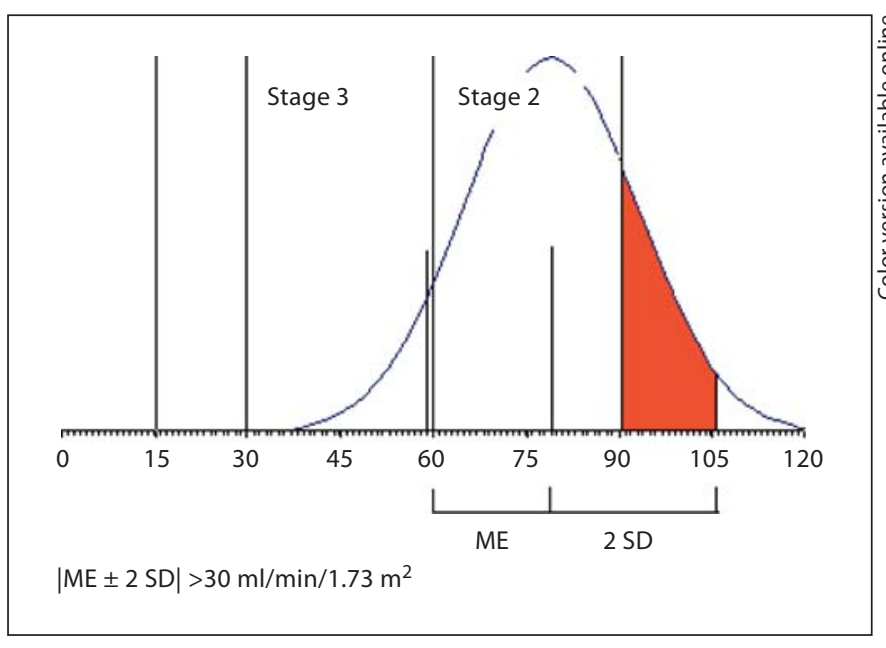

Fig. A. Normal distribution of repeated CG-estimated GFR for a patient with a measured GFR of $59 \mathrm{ml} / \mathrm{min} / 1.73 \mathrm{~m}^{2}$ (stage 3 CKD) after applying an $\mathrm{ME} \pm \mathrm{SD}$ of $19.9 \pm 13.8 \mathrm{ml} / \mathrm{min} / 1.73 \mathrm{~m}^{2}$ [from 29]. Grey (online red) indicates estimates that misclassify the patient by two stages and also belong to the $95 \%$ confidence interval of the distribution.

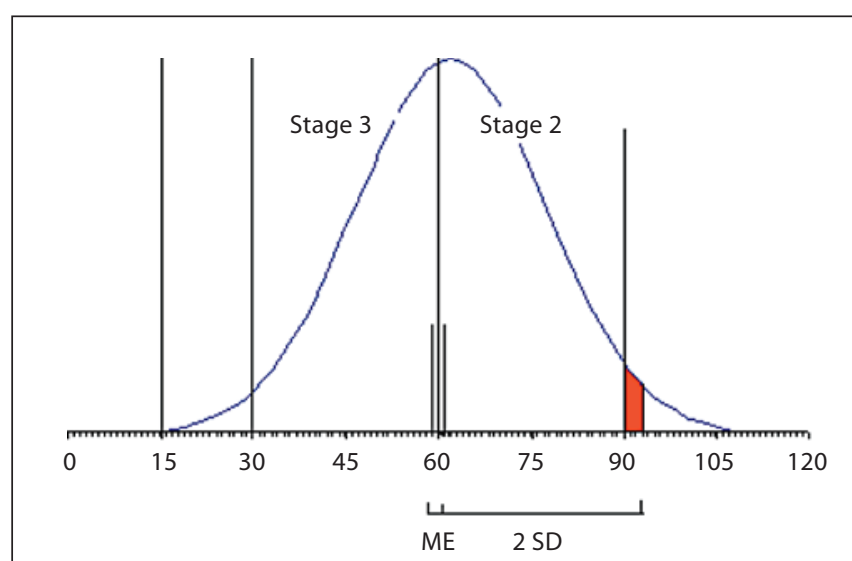

$|\mathrm{ME} \pm 2 \mathrm{SD}|>30 \mathrm{ml} / \mathrm{min} / 1.73 \mathrm{~m}^{2}$

Fig. C. Normal distribution of repeated CG-estimated GFR for a patient with a measured GFR of $59 \mathrm{ml} / \mathrm{min} / 1.73 \mathrm{~m}^{2}$ (stage 3 CKD) after applying an $\mathrm{ME} \pm \mathrm{SD}$ of $1.9 \pm 15.4 \mathrm{ml} / \mathrm{min} / 1.73 \mathrm{~m}^{2}$ [from 23]. Grey (online red) indicates estimates that misclassify the patient by two stages and also belong to the $95 \%$ confidence interval of the distribution.

MDRD versus Cockcroft-Gault Formula for GFR Estimation

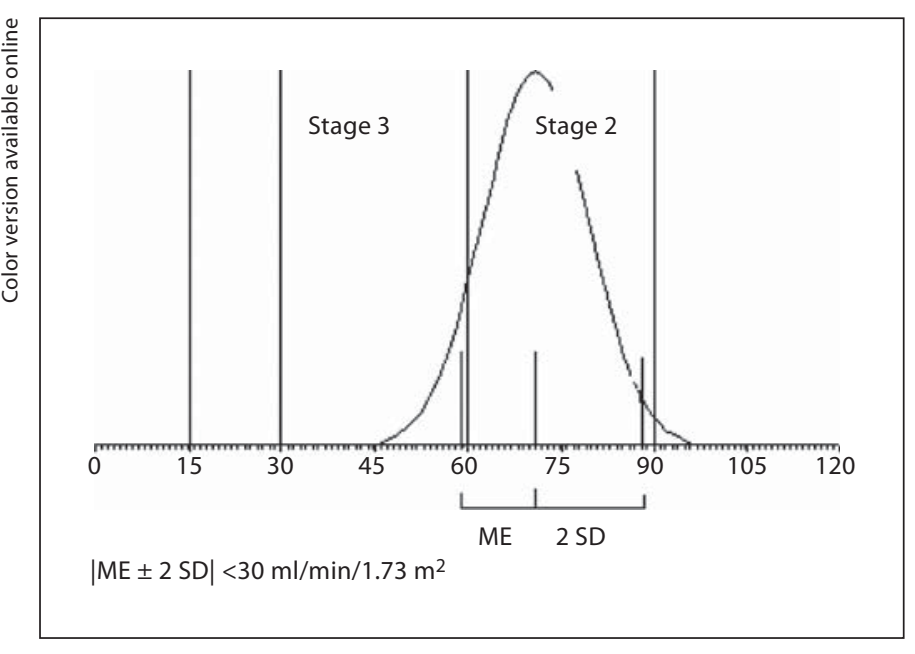

Fig. B. Normal distribution of repeated MDRD-estimated GFR for the same patient as in figure A, after applying an ME \pm SD of $12 \pm 8.5 \mathrm{ml} / \mathrm{min} / 1.73 \mathrm{~m}^{2}$ [from 29]. No grey is shown because there is no estimate that misclassifies the diagnosis by two stages and also belongs to the $95 \%$ confidence interval of the distribution.

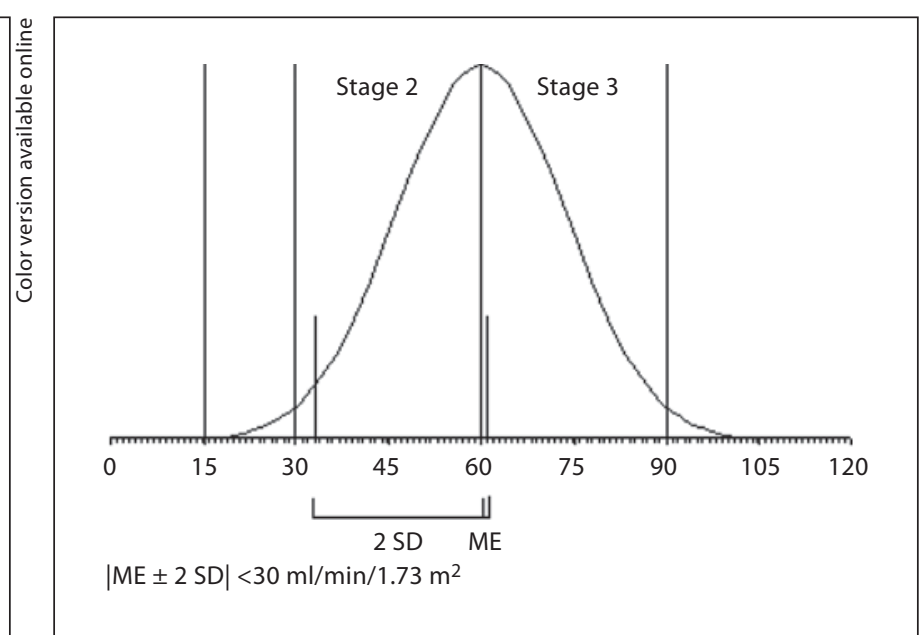

Fig. D. Normal distribution of repeated MDRD-estimated GFR for a patient with a measured GFR of $61 \mathrm{ml} / \mathrm{min} / 1.73 \mathrm{~m}^{2}$ (stage 2 CKD) after applying an $\mathrm{ME} \pm \mathrm{SD}$ of $-1 \pm 13.7 \mathrm{ml} / \mathrm{min} / 1.73 \mathrm{~m}^{2}$ [from 23]. No grey is shown because no estimate misclassifies diagnosis by two stages and also belongs to the $95 \%$ confidence interval of the distribution. The curve is generated in the same direction as the bias (e.g. negative).

Nephron Clin Pract 2010;116:c172-c186 


\section{References}

$>1$ Levey AS, Coresh J, Greene T, Stevens LA, Zhang YL, Hendriksen S, Kusek JW, Van Lente F: Using standardized serum creatinine values in the modification of diet in renal disease study equation for estimating glomerular filtration rate. Ann Intern Med 2006;145:247-254.

$\checkmark 2$ Levey AS, Bosch JP, Lewis JB, Greene T, Rogers N, Roth D: A more accurate method to estimate glomerular filtration rate from serum creatinine: a new prediction equation. Modification of Diet in Renal Disease Study Group. Ann Intern Med 1999;130:461-470.

13 Cockcroft DW, Gault MH: Prediction of creatinine clearance from serum creatinine. Nephron 1976;16:31-41.

$\checkmark 4$ Lamb EJ, Wood J, Stowe HJ, O’Riordan SE, Webb MC, Dalton RN: Susceptibility of glomerular filtration rate estimations to variations in creatinine methodology: a study in older patients. Ann Clin Biochem 2005;42: $11-18$.

5 Barroso S, Martínez JM, Martín MV, Rayo I, Caravaca F: Accuracy of indirect estimates of renal function in advanced chronic renal failure patients (in Spanish). Nefrologia 2006;26:344-350.

6 Karstila K, Harmoinen AP, Lehtimäki TJ, Korpela MM, Mustonen JT, Saha HH: Measurement of the kidney function in patients with rheumatoid arthritis: plasma cystatin C versus ${ }^{51} \mathrm{Cr}$-EDTA clearance. Nephron Clin Pract 2008;108:c284-c290.

-7 Gault MH, Longerich LL, Harnett JD, Wesolowski C: Predicting glomerular function from adjusted serum creatinine. Nephron 1992;62:249-256.

$\checkmark 8$ Whiting P, Rutjes AW, Reitsma JB, Bossuyt PM, Kleijnen J: The development of QUADAS: a tool for the quality assessment of studies of diagnostic accuracy included in systematic reviews. BMC Med Res Methodol 2003;3:25.

-9 Klahr S, Levey AS, Beck GJ, Caggiula AW, Hunsicker L, Kusek JW, Striker G: The effects of dietary protein restriction and bloodpressure control on the progression of chronic renal disease. Modification of Diet in Renal Disease Study Group. N Engl J Med 1994;330:877-884.

10 Beck GJ, Berg RL, Coggins CH, Gassman JJ, Hunsicker LG, Schluchter MD, Williams GW: Design and statistical issues of the Modification of Diet in Renal Disease Trial. The Modification of Diet in Renal Disease Study Group. Control Clin Trials 1991;12: 566-586.

-11 Kusek JW, Coyne T, de Velasco A, Drabik MJ, Finlay RA, Gassman JJ, Kiefer S, Powers SN, Steinman TI: Recruitment experience in the full-scale phase of the Modification of Diet in Renal Disease Study. Control Clin Trials 1993;14:538-557.
12 Vervoort G, Willems HL, Wetzels JF: Assessment of glomerular filtration rate in healthy subjects and normoalbuminuric diabetic patients: validity of a new (MDRD) prediction equation. Nephrol Dial Transplant 2002;17: 1909-1913.

$>13$ Burkhardt H, Hahn T, Gretz N, Gladisch R: Bedside estimation of the glomerular filtration rate in hospitalized elderly patients Nephron Clin Pract 2005;101:c1-c8.

14 Fehrman-Ekholm I, Skeppholm L: Renal function in the elderly ( $>70$ years old) measured by means of iohexol clearance, serum creatinine, serum urea and estimated clearance. Scand J Urol Nephrol 2004;38:73-77.

15 Lewis J, Agodoa L, Cheek D, Greene T, Middleton J, O’Connor D, Ojo A, Phillips R, Sika M, Wright J Jr: Comparison of cross-sectional renal function measurements in African Americans with hypertensive nephrosclerosis and of primary formulas to estimate glomerular filtration rate. Am J Kidney Dis 2001;38:744-753.

16 MacAulay J, Thompson K, Kiberd BA, Barnes DC, Peltekian KM: Serum creatinine in patients with advanced liver disease is of limited value for identification of moderate renal dysfunction: are the equations for estimating renal function better? Can J Gastroenterol 2006;20:521-526.

17 Bland JM, Altman DG: Measuring agreement in method comparison studies. Stat Methods Med Res 1999;8:135-160. Review.

18 Bland JM, Altman DG: Statistical methods for assessing agreement between two methods of clinical measurement. Lancet 1986; 307-310

19 West MJ: Stereological methods for estimating the total number of neurons and synapses: issues of precision and bias. Trends Neurosci 1999;22:51-61.

20 Walther BA, Moore JL: The concepts of bias precision and accuracy, and their use in testing the performance of species richness estimators, with a literature review of estimator performance. Ecography 2005;28:815-829.

21 Stevens LA, Zhang Y, Schmid CH: Evaluating the performance of equations for estimating glomerular filtration rate. J Nephrol 2008;21:797-807.

22 Taylor BN, Kuyatt CE: Guidelines for evaluating and expressing the uncertainty of NIST measurement results. NIST Technical Note 1297. Gaithersburg, National Institute of Standards and Technology, 1994.

-23 Froissart M, Rossert J, Jacquot C, Paillard M, Houillier P: Predictive performance of the modification of diet in renal disease and Cockcroft-Gault equations for estimating renal function. J Am Soc Nephrol 2005;16: 763-773.

24 Lin LI: A concordance correlation coefficient to evaluate reproducibility. Biometrics 1989;45:255-268.
25 McBride GB: Using Statistical Methods for Water Quality Management: Issues, Problems and Solutions. Wiley, New York, 2005.

26 Kuan Y, Hossain M, Surman J, El Nahas AM, Haylor J: GFR prediction using the MDRD and Cockcroft and Gault equations in patients with end-stage renal disease. Nephrol Dial Transplant 2005;20:2394-2401.

27 Ibrahim H, Mondress M, Tello A, Fan Y, Koopmeiners J, Thomas W: An alternative formula to the Cockcroft-Gault and the modification of diet in renal diseases formulas in predicting GFR in individuals with type 1 diabetes. J Am Soc Nephrol 2005;16: 1051-1060.

28 Fontseré N, Bonal J, Navarro M, Riba J, Fraile M, Torres F, Romero R: A comparison of prediction equations for estimating glomerular filtration rate in adult patients with chronic kidney disease stages 4-5. Effect of nutritional status and age. Nephron Clin Pract 2006;104:c160-c168.

-29 Delanaye P, Nellessen E, Grosch S, Depas G, Cavalier E, Defraigne JO, Chapelle JP, Krzesinski JM, Lancellotti P: Creatinine-based formulae for the estimation of glomerular filtration rate in heart transplant recipients. Clin Transplant 2006;20:596-603.

$>30$ Smilde TD, van Veldhuisen DJ, Navis G, Voors AA, Hillege HL: Drawbacks and prognostic value of formulas estimating renal function in patients with chronic heart failure and systolic dysfunction. Circulation 2006;114:1572-1580.

31 Macisaac RJ, Tsalamandris C, Thomas MC, Premaratne E, Panagiotopoulos S, Smith TJ, Poon A, Jenkins MA, Ratnaike SI, Power DA, Jerums G: Estimating glomerular filtration rate in diabetes: a comparison of cystatin-Cand creatinine-based methods. Diabetologia 2006;49:1686-1689.

32 Ibrahim HN, Rogers T, Tello A, Matas A: The performance of three serum creatininebased formulas in estimating GFR in former kidney donors. Am J Transplant 2006;6: 1479-1485.

33 Rigalleau V, Lasseur C, Perlemoine C, Barthe N, Raffaitin C, Liu C, Chauveau P, BailletBlanco L, Beauvieux MC, Combe C, Gin H: Estimation of glomerular filtration rate in diabetic subjects: Cockcroft formula or modification of diet in renal disease study equation? Diabetes Care 2005;28:838-843.

-34 Rigalleau V, Lasseur C, Raffaitin C, Perlemoine C, Barthe N, Chauveau P, Combe C, Gin H: The Mayo Clinic quadratic equation improves the prediction of glomerular filtration rate in diabetic subjects. Nephrol Dial Transplant 2007;22:813-818.

-35 Rigalleau V, Lasseur C, Perlemoine C, Barthe N, Raffaitin C, Chauveau P, Combe C, Gin H: Cockcroft-Gault formula is biased by body weight in diabetic patients with renal impairment. Metabolism 2006;55:108-112. 
>36 Bostom AG, Kronenberg F, Ritz E: Predictive performance of renal function equations for patients with chronic kidney disease and normal serum creatinine levels. J Am Soc Nephrol 2002;13:2140-2144.

-37 Kingdon EJ, Knight CJ, Dustan K, Irwin AG, Thomas M, Powis SH, Burns A, Hilson AJ, Black CM: Calculated glomerular filtration rate is a useful screening tool to identify scleroderma patients with renal impairment. Rheumatology (Oxford) 2003;42:26-33.

-38 Poggio ED, Wang X, Greene T, Van Lente F, Hall PM: Performance of the modification of diet in renal disease and Cockcroft-Gault equations in the estimation of GFR in health and in chronic kidney disease. J Am Soc Nephrol 2005;16:459-466.

- 39 Cirillo M, Anastasio P, De Santo NG: Relationship of gender, age, and body mass index to errors in predicted kidney function. Nephrol Dial Transplant 2005;20:1791-1798. Epub 2005.

-40 Fontseré N, Salinas I, Bonal J, Bayés B, Riba J, Torres F, Rios J, Sanmartí A, Romero R: Are prediction equations for glomerular filtration rate useful for the long-term monitoring of type 2 diabetic patients? Nephrol Dial Transplant 2006;21:2152-2158.

41 Lin J, Knight EL, Hogan ML, Singh AK: A comparison of prediction equations for estimating glomerular filtration rate in adults without kidney disease. J Am Soc Nephrol 2003;14:2573-2580.

-42 Burkhardt H, Bojarsky G, Gretz N, Gladisch R: Creatinine clearance, Cockcroft-Gault formula and cystatin C: estimators of true glomerular filtration rate in the elderly? Gerontology 2002;48:140-146.

43 Van Rossum LK, Mathot RA, Cransberg K, Vulto AG: Optimal sampling strategies to assess inulin clearance in children by the inulin single-injection method. Clin Chem 2003;49:1170-1179.

-44 Poggio ED, Nef PC, Wang X, Greene T, Van Lente F, Dennis VW, Hall PM: Performance of the Cockcroft-Gault and modification of diet in renal disease equations in estimating GFR in ill hospitalized patients. Am J Kidney Dis 2005;46:242-252.

45 Spruill WJ, Wade WE, Cobb HH 3rd: Comparison of estimated glomerular filtration rate with estimated creatinine clearance in the dosing of drugs requiring adjustments in elderly patients with declining renal function. Am J Geriatr Pharmacother 2008;6: 153-160.
46 National Kidney Foundation: K/DOQI clinical practice guidelines for chronic kidney disease: evaluation, classification, and stratification. Am J Kidney Dis 2002;39(suppl 1):S1-S266.

47 Péquignot R, Belmin J, Chauvelier S, Gaubert JY, Konrat C, Duron E, Hanon O: Renal function in older hospital patients is more accurately estimated using the CockcroftGault formula than the modification diet in renal disease formula. J Am Geriatr Soc 2009;57:1638-1643.

48 Verhave JC, Fesler P, Ribstein J, du Cailar G, Mimran A: Estimation of renal function in subjects with normal serum creatinine levels: influence of age and body mass index. Am J Kidney Dis 2005;46:233-241.

49 Stevens LA, Manzi J, Levey AS, Chen J, Deysher AE, Greene T, Poggio ED, Schmid $\mathrm{CH}$, Steffes MW, Zhang YL, Van Lente F, Coresh J: Impact of creatinine calibration on performance of GFR estimating equations in a pooled individual patient database. Am J Kidney Dis 2007;50:21-35.

50 Delanaye P, Cavalier E, Maillard N, Krzesinski JM, Mariat C: Creatinine calibration in NHANES: is a revised MDRD study formula needed? Am J Kidney Dis 2008;51:709, author reply 709-710.

51 Pedone C, Corsonello A, Incalzi RA, GIFA Investigators: Estimating renal function in older people: a comparison of three formulas. Age Ageing 2006;35:121-126.

52 Stevens LA, Nolin TD, Richardson MM, Feldman HI, Lewis JB, Rodby R, Townsend R, Okparavero A, Zhang YL, Schmid CH Levey AS, Chronic Kidney Disease Epidemiology Collaboration: Comparison of drug dosing recommendations based on measured GFR and kidney function estimating equations. Am J Kidney Dis 2009;54:33-42.

53 White CA, Huang D, Akbari A, Garland J, Knoll GA: Performance of creatinine-based estimates of GFR in kidney transplant recipients: a systematic review. Am J Kidney Dis 2008;51:1005-1015.

54 Branten AJ, Vervoort G, Wetzels JF: Serum creatinine is a poor marker of GFR in nephrotic syndrome. Nephrol Dial Transplant 2005;20:707-711.
55 Charleson HA, Bailey RR, Stewart A: Quick prediction of creatinine clearance without the necessity of urine collection. NZ Med J 1980;92:425-426.

56 Sinton TJ, De Leacy EA, Cowley DM: Comparison of ${ }^{51} \mathrm{Cr}$ EDTA clearance with formulae in the measurement of glomerular filtration rate. Pathology 1986;18:445-447.

57 Nicoll SR, Sainsbury R, Bailey RR, King A, Frampton C, Elliot JR, Turner JG: Assessment of creatinine clearance in healthy subjects over 65 years of age. Nephron 1991;59: 621-625.

58 Cochran M, St John A: A comparison between estimates of GFR using [ $\left.{ }^{99 \mathrm{~m}} \mathrm{Tc}\right] \mathrm{DTPA}$ clearance and the approximation of Cockcroft and Gault. Aust N Z J Med 1993;23: 494-497.

59 Waller DG, Fleming JS, Ramsey B, Gray J: The accuracy of creatinine clearance with and without urine collection as a measure of glomerular filtration rate. Postgrad Med J 1991;67:42-46.

-60 Luke DR, Halstenson CE, Opsahl JA, Matzke GR: Validity of creatinine clearance estimates in the assessment of renal function. Clin Pharmacol Ther 1990;48:503-508.

-61 Lemann J, Bidani AK, Bain RP, Lewis EJ, Rohde RD: Use of the serum creatinine to estimate glomerular filtration rate in health and early diabetic nephropathy. Collaborative Study Group of Angiotensin Converting Enzyme Inhibition in Diabetic Nephropathy. Am J Kidney Dis 1990;16:236-243.

62 National Kidney Disease Education Program: NKDEP CKD and Drug Dosing: Information for Providers. http://www.nkdep. nih.gov/professionals/drug-dosing-information.htm\#cockcroft-gault.

63 Roblin I, De Sobarnitsky S, Basselin C, Vial F, Bard E, Dufrene I, Hida H, Laurencin C: Estimated glomerular filtration rate for drug dose adjustment: Cockcroft and Gault or abbreviated MDRD equation? Clin Biochem 2009;42:111-113.

64 Stevens LA, Nolin TD, Richardson MM, Feldman HI, Lewis JB, Rodby R, Townsend R, Okparavero A, Zhang YL, Schmid CH, Levey AS, Chronic Kidney Disease Epidemiology Collaboration: Comparison of drug dosing recommendations based on measured GFR and kidney function estimating equations. Am J Kidney Dis 2009;54:33-42. 


\section{Editorial Comment}

M. El Nahas, Sheffield

This article by Helou reviews a number of publications relating to the accuracy and bias of the two most commonly used formulae in Nephrology, namely the modification of diet in renal disease (MDRD) and CockcroftGault equations. It highlights their respective merit and limitations. The review adds to the endless debate about the value and limitations of calculated glomerular filtration rate (GFR) at different stages of chronic kidney disease (CKD). New formulae, based on serum creatinine (CKD-Epi), cystatin $\mathrm{C}$ or a combination of both, are emerging all the time. It is important as practicing nephrologists to appreciate their value in providing approx- imated GFR values but it is also imperative not to put too many unrealistic and unfounded expectations on such calculations; this is particularly true in individuals with renal function within the normal range, women and in the elderly. Concern has been expressed by some that the reported explosion of detected cases of CKD in communities in the last 10 years may be the consequence of overinterpretation or even misinterpretation of GFR values derived from currently used equations. To know the indications and limitations of calculated GFR is essential for an accurate assessment of the scale of the CKD problem. 